\title{
Sitophilus Weevil Reaction in Upland Rice Elite Lines
}

\author{
Flávia Barbosa Silva Botelho*, Marcela Pedroso Mendes, \\ Rodrigo Teixeira de Carvalho Botelho, Adriano Teodoro Bruzi, Cinthia Souza Rodrigues, \\ Natália Botega Alves, Heloisa Oliveira dos Santos \\ Department of Agriculture, Federal University of Lavras, Lavras, Brazil \\ Email: " flaviabotelho@dag.ufla.br, celapmendes@gmail.com, rbrep@outlook.com.br, \\ adrianobruzi@dag.ufla.br, cinthia-sr@hotmail.com, natalia.b@hotmail.com, heloisasantos@dag.ufla.br
}

Received 4 June 2015; accepted 4 August 2015; published 7 August 2015

Copyright (C) 2015 by authors and Scientific Research Publishing Inc.

This work is licensed under the Creative Commons Attribution International License (CC BY). http://creativecommons.org/licenses/by/4.0/

(c) (i) Open Access

\begin{abstract}
Insects of the genus Sitophilus are among the most destructive pests in rice storage, and the best strategy to control it is to use resistant genotypes. In this study, 26 upland rice elite lines were evaluated for Sitophilus weevil reaction on grain weight. The seeds were placed in plastic recipients stored in a room with temperature and lightning simulating a warehouse environment. The number of living weevils and the grain weight were obtained in two evaluations, one 35 days after storage, and the other 35 days after infestation. The lines differed statistically for number of living weevils and for grain weight in both evaluations. The correlations between these two characters were -0.99 and -0.47 for the first and the second evaluation $(P<0.05)$, respectively. The lines BRS Pepita, AB 112089 and AB 112090 were the most susceptible. Seventeen of the twenty-six elite lines were resistant in both evaluations and could be successfully used in upland rice breeding programs.
\end{abstract}

\section{Keywords}

Oryza Sativa L., Insect Resistance, Rice Weevil, Plant Breeding

\section{Introduction}

Rice (Oryza sativa L.) is one of the most cultivated crops in the world and an excellent source of carbohydrates and protein of human feeding. It is consumed by more than half of the world's population and it is especially important in development countries such as Brazil, playing a strategic role in economic and social politics [1].

${ }^{*}$ Corresponding author.

How to cite this paper: Botelho, F.B.S., Mendes, M.P., de Carvalho Botelho, R.T., Bruzi, A.T., Rodrigues, C.S., Alves, N.B. and dos Santos, H.O. (2015) Sitophilus Weevil Reaction in Upland Rice Elite Lines. American Journal of Plant Sciences, 6, 19161919. http://dx.doi.org/10.4236/ajps.2015.612192 
The world rice production was nearly 724 millions of tons in 2014 [2]. Brazil is the only non-Asian country that is among the ten biggest producers of rice, producing almost 12,400 millions of tons in 2344 hectares in the 2014/2015 growing season [3].

According to Campos [4], 20\% of the Brazilian annual grain production is lost during the period between harvesting and storing, occurring mainly because of the pests attack during storing. The seeds attacked by insects normally present lower vigor due to the consumption of their reserves, and may even start fermentation and favor fungus development [5] [6].

The incidence of storage grain pests can start on the field, during seeds' development and maturing, or after harvesting, during storage, when environmental is favorable or when there is no insect control. Among the storage grain pests, the weevils of Sitophilus genus (Coleoptera: Curculionidae) deserve special attention due to their importance in rice crop, reducing around $20 \%$ of yield production when there is no control of this pest or when the cultivar is susceptive [7] [8]. Upland rice usually is more damaged than irrigated rice, because it has a bigger proportion of malformed grains that greatly favor storage pest attack. The major damages are grain weight reduction, commercial depreciation, poorer germination and nutrient loss.

The best strategy to control rice weevil is to use resistant lines, because it reduces the use of insecticide, the costs of production and grain contamination [7]. Therefore, the aim of this study was to evaluate the performance of rice elite lines in the presence of insects of Sitophilus genus in order to select resistant lines to be incorporated in upland rice breeding programs.

\section{Material and Methods}

The experiment was carried out at the Federal University of Mato Grosso (UFMT), Sinop-MT, Brazil (11 ${ }^{\circ} 51^{\prime} 49^{\prime \prime S}$, $\left.55^{\circ} 28^{\prime} 57^{\prime \prime} \mathrm{W}\right)$. Twenty-six inbred lines from the Upland Rice Breeding Program from "EMBRAPA" (Empresa Brasileira de Pesquisa Agropecuária) were evaluated for grain weight and number of living Sitophilus weevils following a completely randomized design with five replications. These lines were the ones with best performance for several agronomic traits in the field trials carried out by the Brazilian Upland Rice Breeding Program. The plot consisted of a plastic recipient $(500 \mathrm{~mL})$ containing 250 grams of freshly harvested seeds for each genotype. Little holes were made on the cover to allow gases passage, and the recipients were stored in a room with lightening and temperature simulating a warehouse environment $\left(30^{\circ} \mathrm{C}-32^{\circ} \mathrm{C}\right)$.

A first evaluation was performed 35 days after storing in order to determinate the level of infestation from the field. The procedure consisted of the counting of the number of living Sitophilus weevils and plots weighting. Then, the plots were treated with the insecticide Gastoxin ${ }^{\circledR}$ and any speck was cleaned. A 200 grams sample of each plot was infested with ten adults Sitophilus weevils and returned to storage. A second evaluation was performed 35 days after infestation using the same procedure described before.

Analyses of variance were computed using the statistical software SAS [9], transforming the number of weevils data to $\log$ of $x+1$. Genotype's means were compared using the Scott-Knott approach [10] with a probability of $95 \%$. Lastly, the phenotypic correlation between the number of weevils and grain weight were obtained for each evaluation using MSTAT-C software [11].

\section{Results and Discussion}

Highly significant differences $(\mathrm{P}<0.05)$ among genotypes were detected for both characteristics. All experimental accuracies were higher than $84 \%$, indicating high experimental precision [12].

The number of living weevils and grain weight from both evaluations and the Scott-Knott test result are presented in Table 1. Considering the first evaluation, the lines "BRS Pepit", "AB 112089" and "AB 112090" had more than 190 weevils and grain weight reduction, suggesting that these lines were more susceptible to weevil infestation from the field. The other genotypes were considered resistant to the field infestation since they did not have grain weight reduction.

Considering the second evaluation, performed after the provoked infestation, seven of the 26 genotypes had a high level of infestation, with more than 100 weevils (Table 1). However, only three were truly susceptible, showing significant grain weight reduction. the lines "BRS Pepita", "AB 112089" and "AB 112090" maintained their susceptibility in the second evaluation, suggesting that these lines were also sensitive to weevil attack during storage. 
Table 1. Means of living weevils (LW1) and grain weight (GW1) from the first evaluation, and living weevils (LW2) and grain weight (GW2) from the second evaluation on the 26 upland rice lines.

\begin{tabular}{|c|c|c|c|c|c|}
\hline Genotypes & LW1 $^{1}$ & GW1 ${ }^{1}$ & $\mathbf{L W 2}^{1}$ & GW2 ${ }^{1}$ & Lost (\%) \\
\hline Chorinho & $3.60 \mathrm{a}$ & $250.00 \mathrm{a}$ & $14.40 \mathrm{a}$ & $200.00 \mathrm{a}$ & 0 \\
\hline AB 072007 & $21.80 \mathrm{a}$ & $250.00 \mathrm{a}$ & $41.80 \mathrm{a}$ & $190.60 \mathrm{a}$ & 4.7 \\
\hline AB 072044 & $0.60 \mathrm{a}$ & $250.00 \mathrm{a}$ & $13.40 \mathrm{a}$ & $199.00 \mathrm{a}$ & 0.5 \\
\hline AN Cambará & $6.00 \mathrm{a}$ & $250.00 \mathrm{a}$ & $73.60 \mathrm{a}$ & $198.00 \mathrm{a}$ & 1 \\
\hline Carolino & $0.60 \mathrm{a}$ & $250.00 \mathrm{a}$ & $5.80 \mathrm{a}$ & $200.00 \mathrm{a}$ & 0 \\
\hline AB 112093 & $5.20 \mathrm{a}$ & $250.00 \mathrm{a}$ & $6.40 \mathrm{a}$ & $186.80 \mathrm{~b}$ & 6.6 \\
\hline BRS CIRAD 302 & $0.40 \mathrm{a}$ & $250.00 \mathrm{a}$ & $0.40 \mathrm{a}$ & $200.00 \mathrm{a}$ & 0 \\
\hline AB 072063 & $0.20 \mathrm{a}$ & $250.00 \mathrm{a}$ & $17.40 \mathrm{a}$ & $200.00 \mathrm{a}$ & 0 \\
\hline BRS Primavera & $0.20 \mathrm{a}$ & $250.00 \mathrm{a}$ & $39.60 \mathrm{a}$ & $199.00 \mathrm{a}$ & 0.5 \\
\hline BRS Esmeralda & $0.00 \mathrm{a}$ & $250.00 \mathrm{a}$ & $12.20 \mathrm{a}$ & $179.80 \mathrm{~b}$ & 10.1 \\
\hline AB 112108 & $3.00 \mathrm{a}$ & $250.00 \mathrm{a}$ & $8.60 \mathrm{a}$ & $200.00 \mathrm{a}$ & 0 \\
\hline AB 072085 & $16.00 \mathrm{a}$ & $250.00 \mathrm{a}$ & $20.40 \mathrm{a}$ & $195.20 \mathrm{a}$ & 2.4 \\
\hline AB 072047 & $6.40 \mathrm{a}$ & $250.00 \mathrm{a}$ & $121.80 \mathrm{~b}$ & $198.40 \mathrm{a}$ & 0.8 \\
\hline BRS Pepita & $232.00 \mathrm{c}$ & $246.00 \mathrm{~b}$ & $154.20 \mathrm{~b}$ & $181.00 \mathrm{~b}$ & 9.5 \\
\hline AB 112092 & $7.40 \mathrm{a}$ & $250.00 \mathrm{a}$ & $0.80 \mathrm{a}$ & $196.20 \mathrm{a}$ & 1.9 \\
\hline BRS Sertaneja & $0.20 \mathrm{a}$ & $250.00 \mathrm{a}$ & $12.00 \mathrm{a}$ & $200.00 \mathrm{a}$ & 0 \\
\hline AB 072041 & $0.20 \mathrm{a}$ & $250.00 \mathrm{a}$ & $5.60 \mathrm{a}$ & $200.00 \mathrm{a}$ & 0 \\
\hline AB 112089 & $236.20 \mathrm{c}$ & $245.60 \mathrm{~b}$ & $175.20 \mathrm{~b}$ & $182.00 \mathrm{~b}$ & 9 \\
\hline AB 082022 & $1.00 \mathrm{a}$ & $250.00 \mathrm{a}$ & $122.40 \mathrm{~b}$ & $198.60 \mathrm{a}$ & 0.7 \\
\hline H5 & $10,20 \mathrm{a}$ & $250.00 \mathrm{a}$ & $75.60 \mathrm{a}$ & $197.80 \mathrm{a}$ & 1.1 \\
\hline AB 112090 & $193.20 \mathrm{~b}$ & $246.20 \mathrm{~b}$ & $130.40 \mathrm{~b}$ & $169.00 \mathrm{c}$ & 15.5 \\
\hline AB 072035 & $3.60 \mathrm{a}$ & $250.00 \mathrm{a}$ & $61.20 \mathrm{a}$ & $199.20 \mathrm{a}$ & 0.4 \\
\hline AB 072001 & $43.60 \mathrm{a}$ & $249.60 \mathrm{a}$ & $107.40 \mathrm{~b}$ & $191.40 \mathrm{a}$ & 4.3 \\
\hline AB 1120172 & $10.00 \mathrm{a}$ & $250.00 \mathrm{a}$ & $53.00 \mathrm{a}$ & $198.20 \mathrm{a}$ & 0.9 \\
\hline AB 072083 & $0.00 \mathrm{a}$ & $250.00 \mathrm{a}$ & $15.00 \mathrm{a}$ & $200.00 \mathrm{a}$ & 0 \\
\hline AB 082021 & $3.60 \mathrm{a}$ & $250.00 \mathrm{a}$ & $179.00 \mathrm{~b}$ & $193.80 \mathrm{a}$ & 3.1 \\
\hline Mean & 30.97 & 249.51 & 56.45 & 194.39 & \\
\hline Accuracy (\%) & 98.48 & 91.93 & 84.76 & 93.58 & \\
\hline
\end{tabular}

${ }^{1}$ Means followed by the same latter in the column do not differ significantly by the Scott-Knott test with a probability of $95 \%$.

The incidence of weevils and its effect on rice grains quality can start on the field, during seeds' development and maturing, or after harvesting, during storage, when environmental has favorable conditions or when there is no insect control [13]. Therefore, it is essential to identify rice genotypes with resistance to pests attack before harvesting.

It is important to emphasize that most of the lines evaluated in this study are elite lines from advanced generations of the EMBRAPA Upland Rice Breeding Program, in which some are candidates to became new commercial cultivars, with good agronomic traits and grain quality. Since most of the lines showed resistance to weevil attack, they can be successfully used in programs aiming to obtain new cultivars to the MatoGrosso state, espe- 
cially the ones that showed lower percentage of losses in productivity, like the lines "Chorinho", "Carolino", "AB072063", "AB112108" and "BRS Sertaneja".

According to Gallo et al. [14], the insect growing and infestation depend directly on the environmental temperature, as the optimal temperature for weevils' development range between $25^{\circ} \mathrm{C}$ to $33^{\circ} \mathrm{C}$. The mean temperature on the region where this study was carried is around $30^{\circ} \mathrm{C}$, which allows the rapid increase in the insect population during storing, damaging rice grains and reducing its marketing value.

Puzzi [15] discuss that insects eat seed's endosperm first, and the embryo after, reducing seed's weight and nutrients and affecting its germinate power. The arrangement of grain's palea and lemma can favor the resistance to rice weevil attack, since well-formed grains have less attack than malformed ones [16]. Therefore, it is important to study the arrangement of the grain structures from the different genotypes to testify their resistance.

The correlations between the number of living weevils and grain weight were significant $(\mathrm{P}<0.05)$, negative and with large magnitude, -0.99 for the first evaluation and -0.47 for the second evaluation. These results suggest an important association between these characters, as the higher the weevil infestation, the higher the loss on grain weight.

\section{Conclusion}

According to the evaluations of the number of living weevils and the effect of the infestation on grain weight, it is possible to infer that the most susceptible lines are "BRS Pepita", "AB 112089" and "AB 112090". Seventeen of the twenty-six elite lines are resistant in both evaluations and can be successfully used by upland rice breeding programs in order to obtain new cultivars to Mato Grosso State, Brazil.

\section{References}

[1] Walter, M. and Avila, L.A. (2008) Rica: Composition e nutritional characteristics. Ciência Rural, 38, 1184-1192. http://dx.doi.org/10.1590/S0103-84782008000400049

[2] FAO - Food and Agriculture Organization of the United Nations http://www.fao.org

[3] CONAB - National Campaign of Supply http://www.conab.gov.br

[4] Campo, T.B. (2005) Pests of Storage Grains. Proceedings of the Itinerant Meeting of Plant Sanity of the Biological Institute, Ribeirão Preto, 93.

[5] Carvalho, N.M. and Nakagawa, J. (1988) Seeds: Science, Technology and Production. Cargill Foundation, Campinas.

[6] Smiderle, O.J., dos Santos Filho, B.G., dos Santos, D.S.B., Loeck, A.E. and da Silva, A.E. (1997) Physical and Physiologic Quality of Seeds of Irrigated Rice (Oryza sativa L.) under the Attack of Rhizopertha dominica fabricius and Sitophilus sp. during Storage. Revista Brasileira de Sementes, 19, 1-8. http://dx.doi.org/10.17801/0101-3122/rbs.v19n1p1-8

[7] Sousa, J.R., Barrigossi, J.A.F., Boiça Junior, A.L., Gonçalvez, K.K.M., Torres, E.R.S. and Mondego, J.M. (2010) Evaluation of Resistance of Rice Varieties (Oryza sativa L.) under the Attack of Sitophilus oryzae Linnaeus, 1763 (Coleoptera: Curculionidae). Nucleus, 7, 1 259-266. http://dx.doi.org/10.3738/1982.2278-314

[8] Ribeiro, C.S.N., Martins, G.V., Guimarães, J.F.R. and Silva, E.F. (2012) Resistance of Rice Genotypes to Storage Grain. Caatinga, 25, 183-187.

[9] SAS Institute (2008) Statistical Analysis Software. SAS Institute, Cary.

[10] Scott, A. And Knott, M. (1974) Cluster-Analysis Method for Grouping Means in Analysis of Variance. Biometrics, 30, 507-512. http://dx.doi.org/10.2307/2529204

[11] MSTAT-C (1991) A Software Program for the Design, Management and Analysis of Agronomic Research Experiments. Michigan State University, East Lansing.

[12] Resende, M.D.V. and Duarte, J.B. (2007) Precision and Control of the Quality of Experiments of Cultivars Evaluation. Pesquisa Agropecuária Tropical, 37, 182-194.

[13] Arcari, R.L., Arcari, J.A. and Arcari, A.T.M. (2007) Evaluation of Rice Seeds under Insects Attack during Storage. Proceedings of the I Forúm de Educação Ambiental de Ji-Parana, Ji-Parana.

[14] Gallo, D., Nakano, O., SilveiraNeto, S., Carvalho, R.P.L., Batista, G.C., BertiFilho, E., Parra, J.R.P., Zucchi, R.A., Alves, S.B., Vendramin, J.D., Marchini, L.C., Lopes, J.R.S. and Omoto, C. (2002) Entomologia Agrícola. Fealq, Piracicaba.

[15] Puzzi, D. (1986) Grains Supply and Storage. Instituto Campineiro de Ensino Agrícola, São Paulo.

[16] Lara, F.M. (1991) Principals of Plant Resistance to Insects. Ícone, São Paulo. 